\title{
Effect of internal R\&D activities to the accumulation of organizational technical knowledge with the mediation role of absorptive capacity to establish the innovation capability of electronic industries
}

\author{
Bambang Purwanggono* and Yohana Aeria Damyana \\ Department of Industrial Engineering, Faculty of Engineering, Diponegoro University \\ Jl. Prof. Sudharto, Tembalang, Semarang Indonesia 50239 Telp/Fax. (+6224) 7460052
}

\begin{abstract}
Innovation is a strategy for the electronics industry to create a sustainable competitive advantage, in the midst of a rapidly changing environment with all its complexity. Seven AT program as an effort for PT. Hartono Istana Teknologi (Polytron) into enterprise knowledge, will accelerate the innovation process, combined with good organizational technical knowledge management. Organizational technical knowledge will be instrumental in innovation capabilities properly if there is an internal R \& D activities that support and absorptive capacity as a mediator. This study reviewed the organizational technical knowledge influence to innovation capability, the influence of R \& D activities to organizational technical knowledge, as well as the role of absorptive capacity as a mediator. The study was conducted by distributing questionnaires to 130 employees of PT. Hartono Istana Teknologi. Data processing was conducted using SEM. The results showed that the absorptive capacity mediate the relationship between R \& D activities and organizational technical knowledge by $51 \%$, and organizational technical knowledge affect innovation capabilities by $64 \%$.
\end{abstract}

\section{Introduction}

Currently business competition and Indonesian economy are increasing, coupled with the policy of ASEAN Economic Community (AEC) which was implemented in 2015. In realizing AEC, all ASEAN countries should be liberalizing trade. This requires industries to become more competitive and responsive to market change and consumer trends. Indonesia, as the ASEAN member, continues to increase its value-added strategy, especially for export products in order to compete with other ASEAN member countries. Among the 10 Indonesian export commodity, electronic products is one commodity that considered to have potentials to be improved. (Ministry of Commerce of the Republic of Indonesia, 2010)

Innovation becomes an important part in the progress of electronic industry of PT. Hartono Istana Teknologi with brand name Polytron. This is demonstrated by the inclusion the role of innovation in the second point of 7AT corporate identity. The second point of 7AT corporate identity defined as superior in producing new products that are innovative, unique, and consiederd as customers' favourite.'.

However, 7AT corporate identity has not been yet well implemented. Based on interviews, employee management feels a lesser role in providing knowledge- based innovation advice to the firm. In fact, to become a more competitive industry, PT. Hartono Istana Teknologi required to be able to optimize existing resources, including knowledge resources. For this reason the organization's ability to optimize existing knowledge resources are extremely important to accelerate the innovation capabilities (Subramaniam and Youndt, 2005). Knowledge management then deemed capable of managing knowledge that circulating in each and between departments.

Various studies state that the performance of innovation has a positive effect on knowledge management, especially the organizational technical knowledge's firm accumulation. Organizational technical knowledge defined as a credible information that has potential value for an organization (Hult, 2003 in Wang et al., 2009). This positive correlation is described by Cohen and Levinthal (1990) who argued that the ability to evaluate and utilize technical organizational knowledge is a function of the level of innovation. At the most basic level, organizational technical knowledge to include basic skills, or even usage the same language, must also include the latest scientific knowledge or technological developments in the firm.

According to Pavitt, Tornatzky and Fleischer in Attewell (1992), organizational technical knowledge accumulated through output of knowledge from the 
activities of research and development centers or hereinafter referred as internal $\mathrm{R} \& \mathrm{D}$ activities. Murovec (2008) explains further that the output of internal R \& D's firm activities cannot be directly used by the firm without absorptive capacity of the firm itself, so that the function of absorptive capacity is to mediate the relationship between internal R \& D activities and organizational technical knowledge. The firm with higher absorptive capacity will be more sensitive to the flow of knowledge from internal R \& D activities. The absorptive capacity of the firm determines which knowledge will be applied in the firm, while the absorptive capacity itself depends on the extent to how the flow of knowledge of internal R \& $\mathrm{D}$ activities of the firm. Internal $\mathrm{R} \& \mathrm{D}$ activities and absorptive capacity need to be examined as variables to determine the effect of organizational technical knowledge accumulation on innovation capabilities.

In this study a problem that can be defined is how the innovation capabilities of PT. Hartono Istana Teknologi influenced by organizational technical knowledge accumulation, taking into account the internal $\mathrm{R} \& \mathrm{D}$ activities as a source of knowledge in the firm mediated by absorptive capacity. The purpose of this study was to investigate the influence between variables research on enterprise innovation capabilities using Structural Equation Modeling (SEM), the result will be basic of recommendations for PT. Hartono Istana Teknologi improvements to increase the innovation capability.

\section{Research Methodology (Organizational Technical Knowledge)}

Organizational technical knowledge, which is part of the tacit knowledge in the context of knowledge management, is considered important in the development of the firm's knowledge. This knowledge affects the perception and intensity of employees in the use of technology in the firm because of higher individual organizational technical knowledge will allow employees to work more with sophisticated equipment.

Attewell (1992) claims that organizational technical knowledge considered essential in the success of the firm innovation achievement. Learn and communicate existing organizational technical knowledge needed for successful innovation better because of the amount and clarity of information within the firm will continue to accumulate along with increasing experience of the firm.

Bedard, et al. (2003) adds that the individual organizational technical knowledge that optimally accumulated will make people to have the perception that the technology applied by the firm is quite easy to apply. The firm will tend to delay the adoption of complex technologies to companies that have already obtained sufficient organizational technical knowledge as a basis to implement and operate the technology successfully.

\subsection{Internal R\&D Activities}

According to Pavitt, Tornatzky and Fleischer in Attewell (1992) basic organizational technical knowledge innovation can come from internal and external sources.
Internal source is based on the activity of research and development centers. Attewell (1992) explains, the success of an innovation depends on the development of new organizational technical knowledge in the innovation process, one of which organizational technical knowledge derived from $\mathrm{R} \& \mathrm{D}$ activities within the firm.

Internal $\mathrm{R} \& \mathrm{D}$ activities are sources of internal knowledge that are important for a firm and have shown to have a significant influence on innovation, because if investment in internal $\mathrm{R} \& \mathrm{D}$ activities grew, the firm will be more motivated to innovate (Rustika, 2011).

Ellitan (2006) adds that companies which innovate, improve internal sources of innovation usage through R \& $\mathrm{D}$, and investing in technology will be able to achieve better performance than the firm with low level implementation of the innovation strategy or do not have the innovation strategy at all. Companies that decide to be innovative need actively understand and complement R \& $\mathrm{D}$ activities' program and procure external agreements and technology acquisitions.

\subsection{Absorptive Capacity}

The concept of absorptive capacity first introduced by Cohen and Levinthal (1990), they define the absorptive capacity as the extent of the firm's ability to identify new organizational technical knowledge, assimilate, and apply organizational technical knowledge to achieve organizational goals.

Cassiman (2002) and Murovec (2008) adds that the organization/firm trying to improve gains in organizational technical knowledge through investments in absorptive capacity. Absorptive capacity is one of the important concepts in organizational research in the recent years. Organizational technical knowledge that can be practiced in the firm is dependent on the firm's absorptive capacity. The firm with higher absorptive capacity will be more sensitive to the presence of organizational technical knowledge. In other words, the firm's ability to identify and recognize organizational technical knowledge also depends on the absorptive capacity of the firm.

\subsection{Innovation Capability}

Innovation is an effort to maintain the existence of the organization in the competitive environment. Innovation is expected to respond to the complexity of the environment and the dynamic changes in the environment, especially in a tight competition and create resources for competitive advantage. This can be achieved through the introduction of new technologies, new applications in products and services, development of new markets, and the introduction of new forms of organization. According to Santoso in Iksan (2010), the main objective of innovation is increasing the sources of power, money, and means including organizational structures and procedures. Innovation as a strategic component in many companies to respond to the speed of technological change that cannot be predicted, and motivated by a dependence on high technology and firm 
experienced a rapid response in the form of products and procedures for the delivery of the product. Innovation is done with the aim of lowering the level of costs, improve efficiency, delivering good quality at fair prices, the greater possibility of obtaining profit and growth.

According to Lawson and Samson (2001), organizational innovation capability is the ability to integrate the capabilities and resources of their companies to successfully stimulate the development of innovation in the firm. Includes activities to define the purpose and objectives of innovation, selecting strategic arena, develop strategic map, and allocate resources.

\subsection{SEM (Structural Equation Modeling) Methods}

Based on the conceptual model and hypotheses made, this study uses Structural Equation Modeling (SEM). SEM can explain and illustrate the relationship patterns between variables observed with latent variables through the indicators. Unlike regression in general can only explain the causal relationship between the variables observed only.

This study focuses on firm's behavior or perception on innovation capabilities. Behavior is a variable that cannot be observed directly, or so-called latent variables. The use of latent variables in a multiple regression cause measurement errors that affect the estimation of the parameters of the biased-Unbiased angle and the size of the variance. By SEM, this measurement issue is addressed through the existing equations in the measurement model. The parameters of the equation is the load factor of the latent variables of indicators or variables observed. So, SEM models in addition to providing information about the causal relationship between the simultaneous the variables, also provide information about the load factor and errors of measurement.

Viewing excellence SEM and conceptual models that have been described, it is suitable to test the model innovation capabilities using SEM method, because there is latent variables such as internal $\mathrm{R} \& \mathrm{D}$ activities, the absorptive capacity, organizational technical knowledge, and innovation capabilities. In a model of SEM, a latent variable can serve as exogenous or endogenous variables. A dependent variable can be the independent variable to another variable.

\section{Hypotheses (Organizational Technical Knowledge Accumulation)}

Innovation is a complex process in which new knowledge is applied for commercial purposes. The new knowledge generated through a cumulative process in which the knowledge that already exists will be changed, modified, and improved. The role of knowledge flows to the success of the innovation process has long been recognized. The success of an innovation depends on the development of new knowledge in the innovation process, one of which is the knowledge that comes from the firm's R \& D activity. Firm's R \& D activity is also a source of organizational technical knowledge development (Attewell, 1992).
In a product development, internal $\mathrm{R} \& \mathrm{D}$ activities must be able to dig information up whether they will develop products that other companies have done (Huston, 2006). Growing knowledge from information exploring activity will be useful for increasing the firm's profits and competitiveness against the firm's competitors. The absorptive capacity is the extent to which the firm's ability to identify new external knowledge, assimilate, and apply knowledge to achieve organizational goals. Absorptive capacity of the firm determines which organizational technical knowledge that will be applied in the firm, while the absorptive capacity itself depends on the extent of knowledge of internal $R$ \& D activities of the firm. Knowledge that can be implemented in firm depending on the absorptive capacity of the firm itself (Murovec, 2008). Firms with higher absorptive capacity will be more sensitive to the knowledge from internal $\mathrm{R} \& D$. In addition, the firm's ability to identify and recognize the type of organizational technical knowledge also depends on the absorptive capacity of the firm itself. If the Internal R \& D Activities have complex knowledge, the firm will more easily acquire knowledge. Absorptive capacity become intercede so that the flow of knowledge from Internal R \& D Activities can be processed with optimal become accumulated organizational technical knowledge. Because of its nature as an intermediary between Internal R \& D Activities and organizational technical knowledge accumulation, the absorptive capacity is referred as $a$ mediator (Hatani, 2013).

H1: internal $R$ \& $D$ activities have a positive influence to the accumulation of organizational technical knowledge

H2: internal $R$ \& $D$ activities have a positive influence to the absorptive capacity

H3: The absorptive capacity has a positive effect to the accumulation of organizational technical knowledge

H4: The relationship between internal $R$ \& $D$ activities to the accumulation of organizational technical knowledge influenced indirectly (mediation) by the absorptive capacity

\subsection{Innovation Capability}

Organizational technical knowledge is credible information that has potential value for an organization (Hult, 2003 in Wang et al., 2009). This positive correlation is described by Cohen and Levinthal (1990), who argued that the ability to evaluate and utilize organizational technical knowledge is a function of the level of innovation. At the most basic level, organizational technical knowledge including basic skills, or even use the same language, can also include the latest scientific knowledge or technological developments in the firm. Companies tend to delay the adoption of complex technologies, untill the firm acquire sufficient organizational technical knowledge to implement and operate the technology successfully. Organizational technical knowledge considered essential in the success of the firm achievement of innovation. Learning and 
communicating organizational technical knowledge are needed for successful innovation, because the bigger number and clarity of the information in the firm would be a greater advantage than the previous corporate's experiences (Attewell, 1992).

H5: Accumulation of organizational technical knowledge has a positive effect on innovation capabilities

Based on the description of the previous hypotheses, the conceptual model can be made as follows:

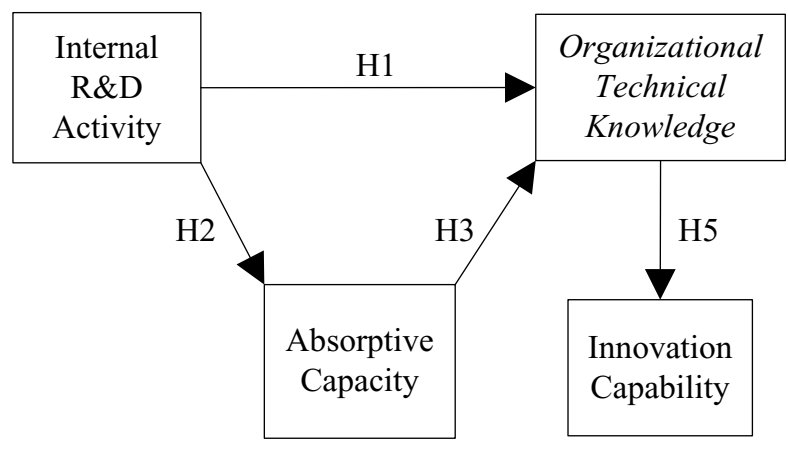

Figure 1 Model Research

\section{Results and Discussion}

After we distributed questionnaires, then data processing is done with the help of software SmartPLS version 2.0.

\subsection{Convergent Validity}

Convergent validity is defined as a measure of whether these indicators can measure a construct precisely. An indicator is said have good validity and reliability if the loading factor value is larger than 0.7 , but the loading factor 0.5 to 0.6 can still be maintained for a development stage model. Based on the results of the outer loading, all the indicators already meet the convergent validity because it has a loading factor values greater than 0.5 .

\subsection{Discriminant Validity}

Reflective indicators also need to be tested using discriminant validity. Discriminant validity used to test unidimensionality of each construct. This test is done by looking cross loading value shown in Table 1.

\subsection{Composite Reliability}

Reliability test is done by looking at the value of composite reliability in the indicator block that measures the construct. The results will show the composite reliability satisfactory if the value above 0.7 . In the results test, all the variables already demonstrated the value of composite reliability $>0.7$ to be considered reliable.

\subsection{Inner model}

Inner model is a model that specifies the relationship between the constructs or also referred as structural models. Inner model formed after the outer models have been significant overall. In general, the inner models are evaluated by looking at the magnitude of the coefficient lines and also to see the $R$-square for the construct. In addition, the significant value of T-statistics obtained from bootstrapping procedure used to test the hypothesis that built.

Table 1. Cross Loading

\begin{tabular}{|c|c|c|c|c|}
\hline & KAPIN & KAPSER & OTK & R\&D \\
\hline I1 & 0.6297 & 0.2153 & 0.2573 & 0.3117 \\
\hline I2 & 0.6954 & 0.3567 & 0.299 & 0.257 \\
\hline I3 & 0.6996 & 0.4204 & 0.376 & 0.4453 \\
\hline I4 & 0.7042 & 0.3966 & 0.3393 & 0.4368 \\
\hline I5 & 0.6843 & 0.365 & 0.4843 & 0.4202 \\
\hline I6 & 0.7307 & 0.4495 & 0.6504 & 0.4 \\
\hline O1 & 0.4975 & 0.6043 & 0.8096 & 0.5091 \\
\hline O2 & 0.4091 & 0.2011 & 0.5169 & 0.2526 \\
\hline O3 & 0.2989 & 0.251 & 0.5633 & 0.3032 \\
\hline O5 & 0.4927 & 0.6315 & 0.7972 & 0.5527 \\
\hline O6 & 0.4591 & 0.5368 & 0.8275 & 0.3737 \\
\hline O7 & 0.4266 & 0.4096 & 0.59 & 0.3606 \\
\hline O8 & 0.4935 & 0.5342 & 0.8579 & 0.4461 \\
\hline O9 & 0.6051 & 0.561 & 0.8138 & 0.4736 \\
\hline R1 & 0.2619 & 0.2983 & 0.2019 & 0.6282 \\
\hline R2 & 0.3328 & 0.4628 & 0.3459 & 0.6978 \\
\hline R3 & 0.2257 & 0.2964 & 0.2328 & 0.6589 \\
\hline R4 & 0.4363 & 0.4381 & 0.4945 & 0.7628 \\
\hline R5 & 0.4077 & 0.4127 & 0.4594 & 0.7241 \\
\hline R6 & 0.4703 & 0.3967 & 0.4735 & 0.6685 \\
\hline R7 & 0.4199 & 0.4456 & 0.3577 & 0.6088 \\
\hline R8 & 0.2364 & 0.3323 & 0.2658 & 0.5368 \\
\hline R9 & 0.3717 & 0.569 & 0.391 & 0.5893 \\
\hline S1 & 0.3948 & 0.5909 & 0.4306 & 0.4426 \\
\hline S2 & 0.3818 & 0.6216 & 0.3998 & 0.3957 \\
\hline S3 & 0.3825 & 0.5751 & 0.3461 & 0.2202 \\
\hline S4 & 0.1857 & 0.5159 & 0.2468 & 0.3737 \\
\hline S5 & 0.2495 & 0.699 & 0.4041 & 0.4045 \\
\hline S6 & 0.2717 & 0.5484 & 0.4222 & 0.3685 \\
\hline S7 & 0.3602 & 0.6197 & 0.497 & 0.3521 \\
\hline S8 & 0.358 & 0.6907 & 0.4606 & 0.513 \\
\hline S9 & 0.467 & 0.7126 & 0.4734 & 0.4485 \\
\hline
\end{tabular}

Table 2. Path Coefficient

\begin{tabular}{|l|c|c|c|c|c|}
\hline & $\begin{array}{l}\text { Original } \\
\text { Sample }\end{array}$ & $\begin{array}{l}\text { Sample } \\
\text { Mean }\end{array}$ & StDev & $\begin{array}{l}\text { Standar } \\
\text { d Error }\end{array}$ & $\begin{array}{l}\text { T } \\
\text { Statistic } \\
\text { s }\end{array}$ \\
\hline $\begin{array}{l}\text { Kapser } \\
\text {-> Otk }\end{array}$ & 0.508 & 0.528 & 0.138 & 0.138 & 3.676 \\
\hline $\begin{array}{l}\text { Otk -> } \\
\text { Kapin }\end{array}$ & 0.637 & 0.682 & 0.070 & 0.070 & 9.077 \\
\hline $\begin{array}{l}\text { R\&D - } \\
\text { Kapser }\end{array}$ & 0.640 & 0.665 & 0.079 & 0.079 & 8.025 \\
\hline $\begin{array}{l}\text { R\&D - } \\
>\text { Otk }\end{array}$ & 0.247 & 0.228 & 0.148 & 0.148 & 1.668 \\
\hline
\end{tabular}


Table 2 is the result of T-statistical significance values and coefficient parameters of the structural model to test the hypothesis that was built in the study and to determine the influence coefficient between variables in the study.

Original sample estimate value for relationship between internal R \& D activities with organizational technical knowledge accumulation is $0.2479 \quad(\approx 0.25)$, which means that the internal $\mathrm{R} \& \mathrm{D}$ activities have a positive effect to the accumulation of organizational technical knowledge by $25 \%$. While the value of the Tstatistic is 1.6688 , the value does not meet the criteria of the T-statistic $>1.96$. Thus $\mathbf{H 1}$ is rejected. This is because knowledge that generated by R \& D activities can not be directly used by employees of other departments. For example, employees of the HR department and GA have a different understanding of the limits of the $\mathrm{R} \& \mathrm{D}$ department in the 'self design product' knowledge. Whereas the HR department and GA have the same potential to provide innovative ideas. Therefore basic knowledge of existing products and that will be developed as well should be a better understanding of the ability to be shared by all employees of PT. Hartono Istana Teknologi.

Original sample estimate value for relationship between internal $\mathrm{R} \& \mathrm{D}$ activities to the absorptive capacity is $0.6402(\approx 0.64)$, which means that the Internal $\mathrm{R} \& \mathrm{D}$ activities positively influence the absorptive capacity by $64 \%$. While the value of the T-statistic of 8.0258 , the value meets the criteria of the T-statistic $>$ 1.96. Thus $\mathbf{H 2}$ is accepted. The absorptive capacity is the ability of employees to identify, assimilate, and apply new knowledge derived from internal $\mathrm{R} \& \mathrm{D}$ activities. This ability to determine how much information, which comes from internal R \& D activities, which will be useful as an organizational technical knowledge. In terms of the influence of internal R \& D activities of the absorptive capacity by $64 \%$, PT. Hartono Istana Teknologi consider the absorptive capacity is important as a basis for using knowledge of the results of R \& D activity.

Original sample estimate value for relationship between the absorptive capacity to organizational technical knowledge accumulation is $0.5089(\approx 0.51)$, which means that the absorptive capacity have a positive effect to the accumulation of organizational technical knowledge by $51 \%$. While the value of the T-statistic of 3.6765 , the value meets the criteria of the T-statistic> 1.96. Thus $\mathbf{H 3}$ is accepted.

\subsection{Mediation Model Testing}

According Urbayatun (2012), a variable called mediating variables (intervening) if the variables influencing the relationship between the independent variables and the dependent variable. Mediation hypothesis testing can be done with a procedure developed by Sobel in 1982 and known as the Sobel test (Sobel Test). Mediating variables test using this method is done by testing the strength of the independent variable indirect effect (internal R \& D activities) on the dependent variable (organizational technical knowledge) through the mediating variables (absorptive capacity). Based on the results obtained Sobel test T-statistics value 3.342 which means $\mathbf{H} 4$ is accepted. Through the absorptive capacity, the relationship between Internal R \& D activity and the accumulation of organizational technical knowledge becomes stronger. It can be seen from the value of the T-statistical relationship between R \& D activities Internal and accumulation of organizational technical knowledge. The value of the Tstatistic direct relationships at 1.6688 , while involving variable absorptive capacity as a mediating variable then the value of the T-statistic of 3.3426. Increasing the value of T-statistics are much different, this suggests a role absorptive capacity variable proved to strengthen the relationship between internal $\mathrm{R} \& \mathrm{D}$ activities and organizational technical knowledge accumulation as mediating variables.

The original sample estimate value of relationship between the accumulation of organizational technical knowledge with innovation capabilities is $0.6372(\approx 0.64)$, which means that the accumulation of organizational technical knowledge positively influence innovation capabilities by $64 \%$. While the value of the T-statistic of 9.0771, the value meets the criteria of the T-statistic $>$ 1.96. Thus $\mathbf{H 5}$ is accepted. The existence of an innovative organizational culture that makes employees motivated to improve absorptive capability of knowledge for the accumulation of organizational technical knowledge.

\section{Conclusions and Recommendations}

Based on the results of data processing and analysis it can be seen that the result of internal R \& D activities cannot be directly used as an accumulated organizational technical knowledge of the firm. To function optimally, the knowledge which is the result of internal R \& D activities must be identified and understood before it can be implemented into accumulated organizational technical knowledge. The process of identifying, understanding, and applying this knowledge is much dependent on the existence of the absorptive capacity. Maximum accumulation of organizational technical knowledge mediated by absorptive capacity within the firm will boost the firm's innovation capabilities.

Recommendations that can be given to PT. Hartono Istana Teknologi in order to improve the performance of services are based on the relationship of accumulation of organizational technical knowledge and innovation capabilities that have the strongest relationship by $64 \%$, then it should be an effort to improve accumulation of organizational technical knowledge to get the maximum increase of innovation capabilities. Efforts to improve accumulation of organizational technical knowledge cannot be separated from the influence of internal R \& D activities and the absorptive capacity as a mediator, then the firm must do two things: (1) the company should be able to build a knowledge enterprise communications system which serves to establish cooperation between the various internal departments. This system starts with forming a functional unit in the firm that manages the firm's knowledge and is responsible for the exchange of knowledge between departments. Furthermore, making internal corporate portals, such as Telkom internal portal 
(POINT), which serves as a vehicle for the grouping of knowledge, knowledge storage, and sharing knowledge, which in turn will improve the value of companies with innovations that have been created by combining, synthesizing and organizing new knowledge. (2) The company should be able to enhance innovation capabilities in the firm, which is to encourage and facilitate employees to produce, combine, and apply new knowledge in order to increase employee competence. This capability can be built with holding training in the use of new technologies as one program among others.

The authors suggest that further studies should be considering other variables that affect the relationship between accumulation of organizational technical knowledge and innovation capability, such as involving external accumulated technical organizational knowledge factors such knowledge spillover variable (an abundance of knowledge from outside the firm).

Regardless of the limitations, this study is expected to provide benefits as an essential consideration to the firm when implementing the accumulation of organizational technical knowledge to improve innovation capabilities. Being expected from this research is that it can provide guidance for managers to choose the appropriate knowledge management strategy in accordance with the firm's goals. The results of this study are expected to also contribute to academics and practitioners, especially in developing knowledge management literature and innovation management. The results of this study should lead to further research that are much more perfect and provide greater benefits.

\section{References}

1. Ministry of Commerce of the Republic of Indonesia. Menuju ASEAN Economic Community 2015 (2010). Accessed on August 2nd 2014 , from the website ditjenkpi.kemendag.go.id/.../Buku\%20Menuju $\% 20 \mathrm{~A}$ SEAN\%20ECONOMI...

2. M. Subramaniam and M.A. Youndt, The Influence of Intellectual Capital on The Types of Innovative Capabilities. Academy of Management Journal, 48, 450 (2005)

3. C.L. Wang, et al. Knowledge Management Orientation, Market Orientation, and Firm Performance: An Integration and Empirical Examination. Journal of Strategic Marketing, 17, 147 (2009)

4. W. Cohen and D. Levinthal, Absorptive Capacity: A New Perspective on Learning and Innovation. Administrative Science Quarterly, 35, 128 (1990)

5. P. Attewell, Technology Diffusion and Organizational Learning: The Case of Business Computing. Organization Science, 3, 1 (1992)

6. N. Murovec and I. Prodan, The Influence of Organizational Absorptive Capacity on Product and Process Innovation. Organizacija, 41, 43 (2008)

7. J.C. Bedard et al. The Roles of Task and Technical Knowledge in Acceptance of Information Technology Among Preparers and Reviewers of
Audit Workpapers (2003) Accessed on May 24 ${ }^{\text {th }}$, 2014, from the website https://aaahq.org/audit/midyear/02midyear/papers/ TAM-Auditing\%20Midyear\%2012-5.pdf

8. N. Rustika. Analisis Pengaruh Penerapan Akuntansi Manajemen Lingkungan Dan Strategi Terhadap Inovasi Perusahaan (2011). Accessed on May 24 ${ }^{\text {th }}$, 2014, from the website eprints.undip.ac.id/30899/1/Skripsi002.pdf

9. L. Ellitan. Strategi Inovasi dan Kinerja Perusahaan Manufaktur di Indonesia Pendekatan Model Simultan dan Model Sekuensial. Jurnal Manajemen, 6, 1 (2006)

10. B. Cassiman and R. Veugelers, R\&D Cooperation and Spillovers: Some Empirical Evidence from Belgium. The American Economic Review, 92, 1169 (2002)

11. F. Iksan. Dasar - Dasar Kependidikan. (Rineka Cipta, Jakarta, 2010)

12. B. Lawson and D. Samson. Developing Innovation Capability in Organisations: a Dynamic Capabilities Approach. International Journal of Innovation Management, 5, 377 (2001)

13. L. Huston and N. Sakkab. Connect and Develop Inside P\&G New Model for Innovation. Harvard Business Review, R0603C (2006). Accessed on May $14^{\text {th }}$, 2014, from the Harvard Business School Publishing Corporation

14. L. Hatani, D. Zain, B. Wirjodirjo and Djumahir. The Role of Competitiveness as Mediator for the Relation between Supply Chain Flexibility and Firm Performance. Journal of Management Research, 5, 269 (2013)

15. S. Urbayatun and W. Widhiarso. Variabel Mediator dan Moderator dalam Penelitian Psikologi Kesehatan Masyarakat. Jurnal Psikologi, 39, 180 (2012) 